\title{
3D printers in dentistry: a review of additive manufacturing techniques and materials
}

\begin{abstract}
- Leonardo Portilha Gomes da Costa Department of Restorative Dentistry, Hospital for Rehabilitation of Craniofacial Anomalies, University of São Paulo (USP), Bauru, SP, Brazil • Stephanie Isabel Díaz Zamalloa Department of Esthetic Dentistry, Faculty of Dentistry, University of São Paulo (USP), São Paulo, SP, Brazil • Fernando Amorim Mendonça Alves Department of Stomatology, Faculty of Dentistry, University of São Paulo (USP), São Paulo, SP, Brazil • Renan Spigolon Department of Stomatology, Faculty of Dentistry, University of São Paulo (USP), São Paulo, SP, Brazil • Leandro Yukio Mano University of the State of Rio de Janeiro (UERJ), Rio de Janeiro, RJ, Brazil - Claudio Costa Department of Stomatology, Faculty of Dentistry, University of São Paulo (USP), São Paulo, SP, Brazil - Alessandra Mazzo Faculty of Dentistry of Bauru, Hospital for Rehabilitation of Craniofacial Anomalies, University of São Paulo (USP), Bauru, SP, Brazil
\end{abstract}

ABSTRACT | 3D printers manufacture objects used in various dental specialties. Objective: This literature review aims to explore different techniques of current $3 \mathrm{D}$ printers and their applications in printed materials for dental purposes. Methods: The online PubMed databases were searched aiming to find applications of different $3 \mathrm{D}$ printers in the dental area. The keywords searched were $3 \mathrm{D}$ printer, $3 \mathrm{D}$ printing, additive manufacturing, rapid prototyping, 3D prototyping, dental materials and dentistry. Results: From the search results, we describe Stereolithography (SLA), Digital Light Processing (DLP), Material Jetting (MJ), Fused Deposition Modeling (FDM), Binder Jetting (BJ) and Dust-based printing techniques. Conclusion: 3D printing enables different additive manufacturing techniques to be used in dentistry, providing better workflows and more satisfying clinical results.

DESCRIPTORS | Printing, Three-Dimensional; Dental Materials; Dentistry.

RESUMO | Impressoras 3D na odontologia: uma revisão de técnicas e materiais para manufatura aditiva • Impressoras 3D fabricam objetos usados em diversas especialidades da odontologia. Objetivo: Esta revisão da literatura busca explorar as diferentes técnicas utilizadas por impressoras $3 \mathrm{D}$, bem como suas aplicações em impressões destinadas à odontologia. Métodos: As bases de dados online da PubMed foram pesquisadas buscando aplicações na odontologia de diferentes impressoras $3 \mathrm{D}$. As palavras-chave buscadas foram $3 D$ printer, 3 D printing, additive manufacturing, rapid prototyping, $3 D$ prototyping, dental materials e dentistry. Resultados: A partir dos resultados da busca descrevemos os métodos de Estereolitografia (SLA), Processamento Digital de Luz (DLP), Jateamento de Material (MJ), Fusão e Deposição de Material (FDM), Jato de Aglutinante (BJ) and Impressão em pó composto. Conclusão: Impressões 3D viabilizam o uso de diferentes técnicas de manufatura aditiva na odontologia, provendo um melhor fluxo de trabalho, além de resultados clínicos mais satisfatórios.

DESCRITORES | Impressão Tridimensional; Materiais Odontológicos; Odontologia.

CORRESPONDING AUTHOR | Leonardo Portilha Hospital for Rehabilitation of Craniofacial Anomalies, University of São Paulo - R. Sílvio Marchione, 3-20 Bauru, SP, Brazi • 05508-000 E-mail: leoportilha@usp.br

- Received Mar 10, 2021 • Accepted Jul 19, 2021 


\section{INTRODUCTION}

$3 \mathrm{D}$ printers create geometrically complex objects through digital modeling. Care and research in dentistry are gradually adopting this technique; digital dentistry manufacturing covers a wide range of technologies, but in its broadest sense, $3 \mathrm{D}$ production may be categorized as either subtractive or additive. In the former process, a numerically controlled machine connected to a CAD/CAM system mills a workpiece (such as a ceramic block). ${ }^{1}$ In the latter, products are built in layers using $3 \mathrm{D}$ digital data, ${ }^{2}$ doing away with molds and machining. ${ }^{3}$

This additive system reproduces virtual models in physical objects through tomography, magnetic resonance or scanner imaging. ${ }^{4-8}$ Additive techniques manufacture objects rapidly and at a low cost, ${ }^{9,10}$ reusing residual materials, ${ }^{8-11}$ allowing the construction of complex structures and the customization of parts in a sustainable manner. ${ }^{12-14}$ $3 \mathrm{D}$ printing assists in the planning of prosthetic, orthodontic and surgical procedures ${ }^{4}$; the making of dental, craniomaxillofacial and orthopedic implants, copings, implant structures,${ }^{15}$ drill guides, among others. ${ }^{16,17}$ In orthognathic surgery, printers can be used to produce occlusal splints, osteotomy or repositioning guides, spacers and fixation plates, as well as anatomical models for preoperative planning and simulation. ${ }^{5}$ Oral rehabilitation can employ these machines for resin prosthesis bases, ${ }^{18}$ ceramic pieces for indirect restorations, ${ }^{12,13,19}$ models for dental preparations ${ }^{20}$ and maxillofacial prostheses. ${ }^{21,22} 3 \mathrm{D}$ printed guides offer reliable predictions and fewer risks of iatrogenic damage than traditional endodontic procedures, ${ }^{23,24} \mathrm{EMS}$ stent-guided, rapid prototyping anomalous teeth, autotransplantation and pre-clinical educational models. ${ }^{25,26}$ In Periodontics, printers can be used in scaffold reconstructions for bone augmentation, alveolar preservation and periodontal regeneration. ${ }^{27}$
$3 \mathrm{D}$ bioprinting uses living cells and growth factors to heal wounds and deformed tissues. ${ }^{28,29} 3 \mathrm{D}$ printing in dentistry allows specialists to individualize products, save money due to small-scale production, share and process patient image data and update educational materials. ${ }^{14,30,31}$

Digitally printed prototypes of the head and neck regions may also achieve more satisfying results than conventional reconstructions. ${ }^{32}$ Studies show that $3 \mathrm{D}$ printing shortens surgical times, ${ }^{4}$ increases procedural safety, and improves outcome predictability. ${ }^{18,33}$ Dentists have even allowed digital models to replace conventional prototype representations in legal matters. ${ }^{34}$

Given the above, this article aims to review the literature on the main $3 \mathrm{D}$ printing techniques used in dentistry.

\section{MATERIAL AND METHODS}

This is a narrative review study conducted in the PubMed database between August and December 2020. The following keywords were searched, associating the Boolean terms AND or OR: " $3 \mathrm{~d}$ printer", "3D printing”, "Additive manufacturing”, "Rapid prototyping”, “3D prototyping”, "Dental Materials" and "Dentistry".

The National Library of Medicine database produced 330 studies when the following formula was applied: ((3d printer OR 3D printing) AND (Additive manufacturing OR Rapid prototyping OR 3D prototyping)) AND (Dental Materials OR Dentistry) to its advanced query box.

After selection, articles published in English were included, which documented different $3 \mathrm{D}$ printer applications in dental specialties. The results were grouped according to the familiarity of the subject (Chart 1), referring to the main 3D printing processes of manufacturers for the dental area and presented in tables and discourse reports. 
Chart 1 | Overview of 3D printing techniques in Digital Dentistry. ${ }^{35}$

\begin{tabular}{|c|c|c|c|c|c|}
\hline $\begin{array}{c}\text { Additive } \\
\text { manufacturing in } \\
\text { Dentistry }\end{array}$ & $\begin{array}{c}\text { Vat } \\
\text { photopolymerization }\end{array}$ & Jetting material & $\begin{array}{l}\text { Thermoplastic } \\
\text { extruded material }\end{array}$ & Binder jetting & Powder bed fusion \\
\hline 3D printing & SLA - DLP & PJ - MJ & FDM & BJ & $\begin{array}{l}\text { SLS-SLF-SLM-SHS- } \\
\text { DMLS-EBM }\end{array}$ \\
\hline Process description & $\begin{array}{l}\text { Liquid photopolymer } \\
\text { in a vat is selectively } \\
\text { cured by UV light. }\end{array}$ & $\begin{array}{l}\text { Inkjet printheads } \\
\text { are used to jet liquid } \\
\text { photopolymers onto a } \\
\text { build platform. }\end{array}$ & $\begin{array}{l}\text { A plastic filament } \\
\text { is melted and } \\
\text { extruded through a } \\
\text { nozzle or hole. }\end{array}$ & $\begin{array}{l}\text { A binding agent is } \\
\text { deposited into a thin } \\
\text { layer of dust through } \\
\text { inkjet nozzles. }\end{array}$ & $\begin{array}{l}\text { A high energy } \\
\text { source selectively } \\
\text { melts dust } \\
\text { particles. }\end{array}$ \\
\hline Acquisition cost & Low - Medium & Relatively high & Low & Medium & High \\
\hline Resolution & High & High & Low & Low & Low \\
\hline $\begin{array}{l}\text { Support structure } \\
\text { required }\end{array}$ & Yes & Yes & Yes & No & No \\
\hline Color print & No & Yes & Yes & Yes & No \\
\hline
\end{tabular}

*Acronyms: SLA = Stereolithography; DLP = Digital Light Processing; PJ = Photopolymer Jetting; MJ = Material Jetting; FDM = Fused Deposition Modeling; BJ = Binder Jetting; SLS = Selective Laser Sintering; FSL = Selective Laser Fusion (SLF); SLM = Selective Laser Melting; SHS = Selective Heat Sintering; DMLS = Direct Metal Laser Sintering; EBM = Electron Beam Machining.

\section{RESULTS}

Stereolithography (SLA); Digital light processing (DLP); Material jetting (MJ); Fused deposition modeling (FDM); Binder jetting (BJ); and
Powder-based printing are the main three-dimensional dentistry processes described in the studies found.

Chart 2 describes these techniques' characteristics and Chart 3 their uses.

Chart 2 | Main characteristics of the printing processes and devices used.

\begin{tabular}{|c|c|c|c|}
\hline Printing Type & Materials used & Strengths & Points to be improved \\
\hline SLA and DPL ${ }^{3,35-37}$ & Photopolymer resin & $\begin{array}{l}\text { 1. Good accuracy, smooth surfaces. } \\
\text { 2. Able to create complex shapes with high resource } \\
\text { resolution. } \\
\text { 3. Low cost and relatively fast technology. }\end{array}$ & $\begin{array}{l}\text { 1. Relatively fragile materials. } \\
\text { 2. Vulnerable to sunlight and heat (only } \\
\text { photopolymers). } \\
\text { 3. Simple material vat; Post-cure } \\
\text { required. }\end{array}$ \\
\hline$M^{3} J^{3,35-37}$ & Photopolymer resin & $\begin{array}{l}\text { 1. High resolution and high-quality finish. } \\
\text { 2. Smoother surface, fine details, multicolor. } \\
\text { 3. Multimaterial capacities with different } \\
\text { hardnesses. }\end{array}$ & $\begin{array}{l}\text { 1. High cost of the printer and materials. } \\
\text { 2. Photopolymers only. } \\
\text { 3. Mechanical properties degrade over } \\
\text { time. }\end{array}$ \\
\hline $\mathrm{FDM}^{3,35-37}$ & $\begin{array}{l}\text { Solid thermoplastic } \\
\text { filaments }\end{array}$ & $\begin{array}{l}\text { 1. Low-cost prototyping. } \\
\text { 2. Multicolor. } \\
\text { 3. Functional applications in plastics (non-critical } \\
\text { load). }\end{array}$ & $\begin{array}{l}\text { 1. Anisotropic mechanical properties. } \\
\text { 2. Fragile materials. } \\
\text { 3. Rough surface and low details (visible } \\
\text { layer lines). }\end{array}$ \\
\hline $\mathrm{BJ}^{3,35-37}$ & $\begin{array}{l}\text { metal, ceramic or } \\
\text { plastic powder }\end{array}$ & $\begin{array}{l}\text { 1. Fast, simple and inexpensive process, structure } \\
\text { support. } \\
\text { 2. Polymer or ceramic colored prototyping. } \\
\text { 3. Large parts and complex metal geometry } \\
\text { capabilities. }\end{array}$ & $\begin{array}{l}\text { 1. Low details and poor mechanical } \\
\text { properties. } \\
\text { 2. Design restriction due to post- } \\
\text { processing. } \\
\text { 3. It cannot be soaked or sterilized by } \\
\text { heat. }\end{array}$ \\
\hline $\begin{array}{l}\text { Powder-based } \\
\text { printing }\end{array}$ & $\begin{array}{l}\text { Resin, metals and } \\
\text { ceramics powder }\end{array}$ & $\begin{array}{l}\text { 1. Printer without support structure (cost reduction) } \\
\text { 2. Complex processing through customized and } \\
\text { complex parts (can use many materials) } \\
\text { 3. Object with excellent physical properties (high } \\
\text { density). }\end{array}$ & $\begin{array}{l}\text { 1. Expensive materials and } \\
\text { manufacturing } \\
\text { 2. Limited object size } \\
\text { 3. Thermal distortion and rough surface. }\end{array}$ \\
\hline
\end{tabular}

*Acronyms: SLA = Stereolithography; DLP = Digital Light Processing; MJ = Material Jetting; FDM = Fused Deposition Modeling; BJ = Binder Jetting. 
Chart 3 | Main uses of printing techniques in dental clinics. ${ }^{2,8,35}$

Printing Type

SLA and DLP

MJ

FDM

BJ

Powder-based printing

\section{Main application areas}

Surgical guides; Custom trays; Silicone provisional try-in; Invisible aligners; Castable; Resin patterns; Temporary restorations; Dental models; Cast fabrication; Cast coping; Wax pattern; Gingiva mask and Biological frameworks.

Custom trays; Model; Implant drilling guides; Surgical guide; Surgical simulation models; Complete denture prototypes.

Custom trays; Prototype of dentures; Medical specialties; Biomedical application; Orthodontic splint models.

Study models; Dental models; Visual prototypes.

Crown copings; Metal frameworks; Prosthesis structures; Partial dentures; Dental implants; Orthopedic implants.

*Acronyms: SLA = Stereolithography; DLP = Digital Light Processing; MJ = Material Jetting; FDM = Fused Deposition Modeling; BJ = Binder Jetting.

\section{Stereolithography (SLA)}

Created in 1986 by Chuck Hull, 3D printing uses UltraViolet (UV) radiation to cross-link photosensitive resin layers. ${ }^{8,38}$ The technique focuses a laser on the reservoir surface (vat) of a liquid polymer - moved vertically whenever one of its layer solidifies - until a solid object is obtained. ${ }^{1,39}$

The process overcomes the limitations of commercially available particulate biomaterials used in oral intraosseous regeneration, ${ }^{40}$ tissue engineering scaffolds and biomedical devices. ${ }^{39}$ The literature reports SLA-made hydroxyapatite calcium phosphate scaffolding cured in a photosensitive ceramic paste that presents a good surface and adequate mechanical properties. ${ }^{12}$ SLA is also the most accurate method for designing hydrogel and microfluidic systems; useful tools when creating artificial microvascular structures in bioprinting. ${ }^{10}$

Thus, the printer can produce highly precise, finely-detailed, smooth transparent objects. ${ }^{9,3} 8$ However, the absence of color and the presence of some partially activated polymers in its products are some of the method's weaknesses. ${ }^{8,38}$

Studies have investigated the possible use of alumina and zirconia ceramics in polycrystalline ceramic crown structures. ${ }^{12}$ Newly developed materials such as polypropylene (PP), acrylonitrilebutadiene-styrene (ABS) and polycarbonate (PC) are challenging when considering the working and processing time and aging properties of these materials. ${ }^{8}$ The literature seems to perceive the temporal and mechanical instabilities of photocurable resins as SLA's only limitation. ${ }^{41}$

\section{Digital light processing (DLP)}

DLP printing has triggered a paradigm shift in traditional $3 \mathrm{D}$ printing modalities by dramatically increasing manufacturing speed and resolution. ${ }^{39}$

A microsystem (called a digital micromirror device) acts as a light switch, projecting light as individual pixels onto a surface. ${ }^{35}$ Below its construction chamber, directly under a glass plate, a projector projects the contour of the component to be produced on the building platform and the resin's application simultaneously solidifies it according to the contour. ${ }^{8}$ In practice, the micro-mirror complex is a precise system that directs light where it is needed by determining its ability to turn the light "on or off" according to a binary code. ${ }^{42}$

DLP can be used with a wide range of monomers and resin systems. ${ }^{43}$ The main difference between DLP and SLA is the light source, since DLP uses a shallow resin vat and a digital light projector located below the resin bath,7 being used to manufacture a single layer of the $3 \mathrm{D}$ object through solidification. ${ }^{44}$ In general, compared to SLA, DLP's system is more efficient for its use of arc lamps, liquid crystal panels or projection sources to cure entire layers of resin at once. ${ }^{45}$

The equipment's mapping system allows for faster production, more sensitive measurements, 
smoother surfaces, and the ability to adapt the final characteristics of the printed object by changing the formulations of photocurable resins. ${ }^{44}$ Its projectors, however, emit broad spectrum light, - most of which falls below $400 \mathrm{~nm}$, the ideal range for the activation of photoinitiators. ${ }^{36}$

\section{Material jetting (MJ)}

Material jetting uses nozzles to layer a photoreactive resin onto charge deflection plates, and then cures it with ultraviolet light. ${ }^{36}$

The technique has appears with many synonyms in the literature: "Polyjet Modeling", "Multijet Modeling", "MultiJet Modeling (MJM)", "Jet Photopolymer/ Photopolymer Blasting” (PJ), "Polyjetting”, and "Multijetting". The principle emulates a conventional inkjet printer; only instead of ink drops, a liquid photomonomer is used for photopolymer jets (PJ/ PPJ) or wax for material jets (MJ/MJP). ${ }^{35}$

MJ controls resin composition better than SLA by dispensing individual drops of resin. The materials can thus be adjusted during the printing process, allowing the manufacturing of heterogeneous objects with the additional possibility of material gradients and extremely high resolution. ${ }^{37}$ Several materials can be printed, including different casting resins and waxes and some silicone-like rubber materials. ${ }^{15}$

MJ is becoming a leading technology in dentistry since parts can be built with various colors and physical properties and print heads can be loaded with various materials in the same process to construct the object. ${ }^{7}$ However, MJ equipment and materials are costly and support materials can be tenacious and difficult to remove. ${ }^{15}$

\section{Fused deposition modeling (FDM)}

FDM printing, also known as Fused Filament Fabrication (FFF), is a manufacturing technique where a $3 \mathrm{D}$ object is constructed by layering extruded molten polymers onto a building platform. ${ }^{46}$
In 1989, Scott Crump invented and patented the FDM of thermoplastic polymers fed mechanically as thin spool filaments to the extrusion printhead..$^{3,47}$ The energy input is involved in the pre-deposition phase to obtain a polymer melt that can be applied through a thin head or print nozzle. ${ }^{43}$ The melted material is deposited on the construction platform, where it cools off and solidifies with each layer.

FDM is currently a robust technology platform and explored worldwide, providing personalized and low-cost $3 \mathrm{D}$ printing, useful in home and office environments. ${ }^{3}$ The system can quickly produce complex structures leading to predictable and economic results, ${ }^{46}$ by using polymers such as polyvinyl alcohol (PVA), acrylonitrile butadiene styrene (ABS), polylactic acid (PLA), polyethylene terephthalate modified glycol (PETG), nylon and thermoplastic elastomers (TPE). ${ }^{48}$

FDM printers' low cost may be the best method for surgeons looking for more accessible rapid prototyping technologies; ABS plastic models printed by the UPplus2 $\AA 3 \mathrm{D}$ printer provide dimensional accuracy comparable to other well-established (and more expensive) rapid prototyping technologies. ${ }^{49}$ However, its employability in the dental field remains underdeveloped ${ }^{35}$ and some disadvantages include using only thermoplastic materials and the difficulty of incorporating cells into the material as thermoplastics melt at temperatures above $37^{\circ} \mathrm{C} .5^{\circ}$

\section{Binder jetting (BJ)}

Binder jetting is characterized as a thin layer of dust particles (metal, polymer or ceramic) deposited on the construction platform, followed by an inkjet printhead dropping adhesive to bond the dust particles selectively layer by layer. ${ }^{15}$

This is a variation of the photopolymer jet process..$^{35} \mathrm{BJ}$ is a flexible technology with several applications, from low-cost $3 \mathrm{D}$ metal printing to color prototyping and large ceramic casting mold 
production; solvents and photosensitive adhesives can also be used as binders. ${ }^{36}$

Compatible with almost all-ceramic materials and similar to traditional manufacturing routes, $\mathrm{BJ}$ presents promising potential in ceramic dental prosthesis applications..$^{51}$ Color pieces can be printed and no support structure is required during printing. ${ }^{35}$ However, its accuracy is currently limited to prosthodontic applications. BJ requires a substantial processing after all layers are applied. ${ }^{37}$

The printed parts' resistance can be affected by chemical and physical interactions between powdered materials and binders, nominal dimensions and part orientation in the print bed, resulting in inconsistencies in, among others, the powder bed flow and the powder-binder curing. ${ }^{51}$ Its attested usefulness in dentistry remains limited to surgical planning models. ${ }^{35}$ More research is required on how well deposition/jet techniques can manufacture dental composites, ceramics and zirconia- based dental restorations. ${ }^{2}$

\section{Powder-based printing}

Dust-based printing technologies apply thermal energy from a laser or electron beam to selectively fuse regions of a powder bed. The two most wellknown systems are Selective Laser Sintering (SLS) and Selective Laser Fusion (SLF) or Selective Laser Melting (SLM). Other related terms are: Selective Heat Sintering (SHS), Direct Metal Laser Sintering (DMLS) and Electron Beam Machining (EBM).

SLS, DMLS and SLM use mirror-directed laser beams, whilst EBM uses high-energy electron beams directed by electromagnetic coils (which require vacuum increasing production costs). ${ }^{7}$ In SLS, the fusion process is partial, since its layered sintering fuses only the surface particles of the material ${ }^{35}$ In SLF, the material's powder is melted directly at the processing point. ${ }^{35}$ Material usually requires preheating of the powder bed at high temperatures to control and reduce the length of cracks and is not dispensed from a nozzle in these two methods. The high temperature of the laser is used to sinter or weld specific regions in a powder bed while a stage moves up or down and the material is added layer by layer, thus generating a $3 \mathrm{D}$ structure; ${ }^{2}$ industrial manufacturing of metallic, ceramic and plastic objects employs powder methods. ${ }^{53}$

The polymers used in this process produce useful anatomical and dental study models, cutting and drilling guides, and engineering/design prototypes. ${ }^{15}$ Polyamide (PA12 or nylon 12) represents the vast majority of commercial SLS materials on the market today. ${ }^{43}$ SLS printing manufactures metal objects adopting DMLS, models that offer potential benefits in the field of implantology. ${ }^{54}$ Several metals and metal alloys are available, including titanium, titanium alloys, cobalt-chromium alloys and stainless steel. ${ }^{15}$

SLS is already being used to print partial dentures and denture structures and for implant bridge structures, the technology can be combined with milling processes to provide high precision connections. ${ }^{15}$ Excellent mechanical properties that make it suitable for industrial applications, selecting highly versatile materials (nylon, polystyrene, metal) and not requiring support structures are advantageous characteristics. The limitations include the high price, making it more affordable for professional $3 \mathrm{D}$ printing companies and the surface finish is quite rough, leading to water absorption and thus affecting the mechanical properties. ${ }^{55}$

\section{DISCUSSION}

Additive manufacturing (AM) can be found in everything nowadays, from construction, engineering, architecture, aerospace engineering, to everyday applications in fashion, food and health. ${ }^{55}$ The development of different $3 \mathrm{D}$ printing techniques has allowed the production of sophisticated pieces whose geometry was previously inconceivable given the topological limitations of traditional 
manufacturing methods..$^{41}$ AM's triumph is its objects' dimensional complexity - their details are often finer than a drilling bit and they are made with little material waste. ${ }^{2,11,56} 3 \mathrm{D}$ printed models present general accuracy comparable to plaster models and present different colors and textures during manufacturing to help differentiate the types of simulated fabrics. ${ }^{24}$

The need for better visualization and surgical results were favored by $3 \mathrm{D}$-printed anatomical models, specific patient guides and prostheses printed in three-dimensional form..$^{57}$

The growing application of various AM techniques in dentistry, manufacturing dental models, surgical guides and occlusal devices is found in the literature. ${ }^{2}$ Simulation models can also contribute to further interdisciplinary dental education..$^{58}$ Dentistry has been drastically changed by technological progress in intraoral scanner, accessibility of $3 \mathrm{D}$ printers and the development of biomaterial impressions. 59 Their application as scaffolds for craniofacial tissue engineering offers great potential as an alternative to autologous bone grafts in alveolar cleft osteoplasty. ${ }^{50,60,61}$ Scaffolds can also be customized internally to target and fix target cells. ${ }^{62}$

Recent studies in the forefront of regenerative dentistry show AM has permitted "bioprinting": the production of supportting components for living cells in complex $3 \mathrm{D}$ functional tissues. ${ }^{63}$ Selecting materials for $3 \mathrm{D}$ bioprinting depends mainly on biocompatibility with cell growth and function and the material's processing characteristics (e.g., viscosity, extrusion capacity and post-printing stability). ${ }^{29}$

A variety of low-cost desktop AM $3 \mathrm{D}$ printers offer high precision and the ability to process a wide range of printing materials, including an increasing number of biocompatible materials. ${ }^{55}$ Binder/powder combinations like polymers, thermoplastic resins, ceramics and metals comprise most of the materials used in dentistry. However, materials such as the cobalt-chromium alloy still lack sufficient research to draw conclusions about the adequacy of their use in dental clinical practices. ${ }^{6}$

A study by Msallem et al.,55 suggests choosing a $3 \mathrm{D}$ printer after considering the technology it uses, its intended application and material budgetary constraints. The effort seems worth it, given the tremendous flexibility in construction material, object geometry, ${ }^{56}$ and mass production customization. ${ }^{64} \mathrm{AM}$ 's effectiveness in medical and dental applications as attested in the production and customization of hearing aids, dental crowns, implants and dentures; biomedical implants for hard and soft tissues, models, splints and custom orthoses/prostheses. ${ }^{65}$

The main limitations include the appearance of steps due to the material's stratification and the difficulty in manufacturing parts of some materials used in dentistry. ${ }^{56}$ In ceramics, different AM procedures have been investigated for their suitability to manufacture parts using selective laser sintering techniques, fused deposition modeling, binder jetting and even stereolithography devices. ${ }^{66}$ Recent improvements in the accuracy of materials and the time and cost-efficiency of $3 \mathrm{D}$ printing are shifting the focus of this new manufacturing method from traditional rapid prototyping applications to manufacturing final parts. ${ }^{64}$

The research objectives regarding the applicability of AM in dentistry are to improve the quality, precision and printing speed; develop new techniques that allow the sintering of pure ceramic powders; prevent thermal distortion or cracks in the SLS and SLM processes and incorporate multiple materials in a single printing step. ${ }^{59}$ Therefore, the key challenge for disseminating $3 \mathrm{D}$ printing in industries concerns materials, mainly the multimaterial printing of the object. ${ }^{41}$

\section{CONCLUSION}

$3 \mathrm{D}$ printing enables rapid prototyping in dentistry through flexible processing and material 
development (polymers, metals and ceramics). Additive manufacturing will constitute a major advance in dental workflow, reducing surgery times, improving biomaterial and orthotic confirmation and, above all, assuring the satisfactory treatment of patients in this new technological era.

\section{REFERENCES}

1. Khaledi AA, Farzin M, Akhlaghian M, Pardis S, Mir N. Evaluation of the marginal fit of metal copings fabricated by using 3 different CAD-CAM techniques: Milling, stereolithography, and 3D wax printer. J Prosthet Dent. 2020;124(1):81-6. doi: 10.1016/j.prosdent.2019.09.002.

2. Alharbi N, Wismeijer D, Osman RB. Additive Manufacturing Techniques in Prosthodontics: Where Do We Currently Stand? A Critical Review. Int J Prosthodont. 2017;30(5):47484. doi: 10.11607/ijp.5079.

3. Ligon SC, Liska R, Stampfl J, Gurr M, Mülhaupt R. Polymers for 3D Printing and Customized Additive Manufacturing. Chem Rev. 2017;117(15):10212-90. doi: 10.1021/acs. chemrev.7booo74.

4. Brito NMSO, Soares RSC, Monteiro ELT, Martins SCR, Cavalcante JR, Grempel RG, et al. Additive Manufacturing for Surgical Planning of Mandibular Fracture. Acta Stomatol Croat. 2016;50(4):348-53. doi: 10.15644/asc50/4/8.

5. Serrano C, van den Brink H, Pineau J, Prognon P, Martelli N. Benefits of $3 \mathrm{D}$ printing applications in jaw reconstruction: A systematic review and meta-analysis. J Craniomaxillofac Surg. 2019;47(9):1387-97. doi: 10.1016/j.jcms.2019.06.008.

6. Zeiderman MR, Pu LLQ. Contemporary reconstruction after complex facial trauma. Burns Trauma. 2020;8:tkaaoo3. doi: 10.1093/burnst/tkaaoo3.

7. Liaw CY, Guvendiren M. Current and emerging applications of 3 D printing in medicine. Biofabrication. 2017;9(2):024102. doi: 10.1088/1758-5090/aa7279.

8. Jockusch J, Özcan M. Additive manufacturing of dental polymers: An overview on processes, materials and applications. Dent Mater J. 2020;39(3):345-54. doi: 10.4012/dmj.2019-123.

9. Hada T, Kanazawa M, Iwaki M, Arakida T, Soeda Y, Katheng A, et al. Effect of Printing Direction on the Accuracy of $3 \mathrm{D}$ Printed Dentures Using Stereolithography Technology. Materials (Basel). 2020;13(15):3405. doi: 10.3390/ma13153405.
10. Magalhães LSSM, Santos FEP, Elias CMV, Afewerki S, Sousa GF, Furtado ASA, et al. Printing 3D Hydrogel Structures Employing Low-Cost Stereolithography Technology. J Funct Biomater. 2020;11(1):12. doi: 10.3390/jfb11010012.

11. Baumgartner S, Gmeiner R, Schönherr JA, Stampfl J. Stereolithography-based additive manufacturing of lithium disilicate glass ceramic for dental applications. Mater Sci Eng C Mater Biol Appl. 2020;116:111180. doi: 10.1016/j. msec.2020.111180.

12. Dehurtevent M, Robberecht L, Hornez JC, Thuault A, Deveaux E, Béhin P. Stereolithography: A new method for processing dental ceramics by additive computer-aided manufacturing. Dent Mater. 2017;33(5):477-85. doi: 10.1016/j. dental.2017.01.018.

13. Methani MM, Revilla-León M, Zandinejad A. The potential of additive manufacturing technologies and their processing parameters for the fabrication of all-ceramic crowns: A review. $\mathrm{J}$ Esthet Restor Dent. 2020;32(2):182-92. doi: 10.1111/jerd.12535.

14. Oberoi G, Nitsch S, Edelmayer M, Janjić K, Müller AS, Agis H. 3D Printing-Encompassing the Facets of Dentistry. Front Bioeng Biotechnol. 2018;6:172. doi: 10.3389/fbioe.2018.00172.

15. Dawood A, Marti Marti B, Sauret-Jackson V, Darwood A. 3D printing in dentistry. Br Dent J. 2015;219(11):521-9. doi: 10.1038/sj.bdj.2015.914.

16. Kim T, Lee S, Kim GB, Hong D, Kwon J, Park JW, et al. Accuracy of a simplified $3 \mathrm{D}$-printed implant surgical guide. $\mathrm{J}$ Prosthet Dent. 2020;124(2):195-201.e2. doi: 10.1016/j.prosdent.2019.06.006.

17. Yeung M, Abdulmajeed A, Carrico CK, Deeb GR, Bencharit S. Accuracy and precision of $3 \mathrm{D}$-printed implant surgical guides with different implant systems: An in vitro study. J Prosthet Dent. 2020;123(6):821-8. doi: 10.1016/j.prosdent.2019.05.027.

18. Cha HS, Park JM, Kim TH, Lee JH. Wear resistance of 3Dprinted denture tooth resin opposing zirconia and metal antagonists. J Prosthet Dent. 2020;124(3):387-94. doi: 10.1016/j.prosdent.2019.09.004.

19. Wang W, Sun J. Dimensional accuracy and clinical adaptation of ceramic crowns fabricated with the stereolithography technique. J Prosthet Dent. 2020;125(4):651-63. doi: 10.1016/j. prosdent.2020.02.032.

20. Höhne C, Rammler T, Schmitter M. 3D Printed Teeth with Included Veneer Preparation Guide. J Prosthodont. 2021;30(1):51-6. doi: 10.1111/jopr.13250. 
21. Fernandes N, van den Heever J, Hoogendijk C, Botha S, Booysen G, Els J. Reconstruction of an Extensive Midfacial Defect Using Additive Manufacturing Techniques. J Prosthodont. 2016;25(7):589-94. doi: 10.1111/jopr.12487.

22. Yadav S, Narayan AI, Choudhry A, Balakrishnan D. CAD/ CAM-Assisted Auricular Prosthesis Fabrication for a Quick, Precise, and More Retentive Outcome: A Clinical Report. J Prosthodont. 2017;26(7):616-21. doi: 10.1111/jopr.12589.

23. Moreno-Rabié C, Torres A, Lambrechts P, Jacobs R. Clinical applications, accuracy and limitations of guided endodontics: a systematic review. Int Endod J. 2020;53(2):214-31. doi: 10.1111/iej.13216.

24. Shah P, Chong BS. 3D imaging, 3D printing and $3 \mathrm{D}$ virtual planning in endodontics. Clin Oral Investig. 2018;22(2):64154. doi: 10.1007/s00784-018-2338-9.

25. Verweij JP, Jongkees FA, Anssari Moin D, Wismeijer D, van Merkesteyn JPR. Autotransplantation of teeth using computeraided rapid prototyping of a three-dimensional replica of the donor tooth: a systematic literature review. Int J Oral Maxillofac Surg. 2017;46(11):1466-74. doi: 10.1016/j.ijom.2017.04.008.

26. Anderson J, Wealleans J, Ray J. Endodontic applications of $3 \mathrm{D}$ printing. Int Endod J. 2018;51(9):1005-18. doi: 10.1111/iej.12917.

27. Gul M, Arif A, Ghafoor R. Role of three-dimensional printing in periodontal regeneration and repair: Literature review. J Indian SocPeriodontol. 2019;23(6):504-10. doi: 10.4103/jisp.jisp_46_19. 28. Smandri A, Nordin A, Hwei NM, Chin KY, Abd Aziz I, Fauzi MB. Natural 3D-Printed Bioinks for Skin Regeneration and Wound Healing: A Systematic Review. Polymers (Basel). 2020;12(8):1782. doi: 10.3390/polym12081782.

29. Unagolla JM, Jayasuriya AC. Hydrogel-based 3D bioprinting: A comprehensive review on cell-laden hydrogels, bioink formulations, and future perspectives. Appl Mater Today. 2020;18:100479. doi: 10.1016/j.apmt.2019.100479.

30. Seifert LB, Schnurr B, Herrera-Vizcaino C, Begic A, Thieringer F, Schwarz F, et al. 3D-printed patient individualised models vs cadaveric models in an undergraduate oral and maxillofacial surgery curriculum: Comparison of student's perceptions. Eur J Dent Educ. 2020;24(4):799-806. doi: 10.1111/eje.12522.

31. Hanisch M, Kroeger E, Dekiff M, Timme M, Kleinheinz J, Dirksen D. 3D-printed Surgical Training Model Based on Real Patient Situations for Dental Education. Int J Environ Res Public Health. 2020;17(8):2901. doi: 10.3390/ijerph17082901.

32. Largo RD, Garvey PB. Updates in Head and Neck Reconstruction. Plast Reconstr Surg. 2018;141(2):271e-285e. doi: 10.1097/prs.0000000000004070.
33. Rogers-Vizena CR, Sporn SF, Daniels KM, Padwa BL, Weinstock P. Cost-Benefit Analysis of Three-Dimensional Craniofacial Models for Midfacial Distraction: A Pilot Study. Cleft Palate Craniofac J. 2017;54(5):612-7. doi: 10.1597/15-281.

34. Aly P, Mohsen C. Comparison of the Accuracy of Three-Dimensional Printed Casts, Digital, and Conventional Casts: An In Vitro Study. Eur J Dent. 2020;14(2):189-93. doi: 10.1055/s0040-1705243.

35. Kessler A, Hickel R, Reymus M. 3D Printing in Dentistry-State of the Art. Oper Dent. 2020;45(1):30-40. doi: 10.2341/18-229-1.

36. Fiedor P, Ortyl J. A New Approach to Micromachining: HighPrecision and Innovative Additive Manufacturing Solutions Based on Photopolymerization Technology. Materials (Basel). 2020;13(13):2951. doi: 10.3390/ma13132951.

37. Crafts TD, Ellsperman SE, Wannemuehler TJ, Bellicchi TD, Shipchandler TZ, Mantravadi AV. Three-Dimensional Printing and Its Applications in Otorhinolaryngology-Head and Neck Surgery. Otolaryngol Head Neck Surg. 2017;156(6):9991010. doi: 10.1177/0194599816678372.

38. Katheng A, Kanazawa M, Iwaki M, Minakuchi S. Evaluation of dimensional accuracy and degree of polymerization of stereolithography photopolymer resin under different postpolymerization conditions: An in vitro study. J Prosthet Dent. 2021;125(4):695-702. doi: 10.1016/j.prosdent.2020.02.023.

39. Yu C, Schimelman J, Wang P, Miller KL, Ma X, You S, et al. Photopolymerizable Biomaterials and Light-Based $3 \mathrm{D}$ Printing Strategies for Biomedical Applications. Chem Rev. 202014;120(19):10695-743. doi: 10.1021/acs.chemrev.9boo810.

40. Le Guéhennec L, Van Hede D, Plougonven E, Nolens G, Verlée $\mathrm{B}$, De Pauw MC, et al. In vitro and in vivo biocompatibility of calcium-phosphate scaffolds three-dimensional printed by stereolithography for bone regeneration. J Biomed Mater Res A. 2020;108(3):412-25. doi: 10.1002/jbm.a.36823.

41. Khatri B, Frey M, Raouf-Fahmy A, Scharla MV, Hanemann T. Development of a multi-material stereolithography $3 \mathrm{D}$ printing device. Micromachines (Basel). 2020;11(5):532. doi: 10.3390/mi11050532.

42. Mangano FG, Admakin O, Bonacina M, Biaggini F, Farronato D, Lerner H. Accuracy of 6 Desktop 3D Printers in Dentistry: A Comparative In Vitro Study. Eur J Prosthodont Restor Dent. 2020;28(2):75-85. doi: https://doi.org/10.1922/ ejprd_205omangano11.

43. Stansbury JW, Idacavage MJ. 3D printing with polymers: Challenges among expanding options and opportunities. Dent Mater. 2016;32(1):54-64. doi: 10.1016/j.dental.2015.09.018. 
44. Ertugrul I. The Fabrication of Micro Beam from Photopolymer by Digital Light Processing 3D Printing Technology. Micromachines (Basel). 2020;11(5):518. doi: 10.3390/mi11050518.

45. Sherman SL, Kadioglu O, Currier GF, Kierl JP, Li J. Accuracy of digital light processing printing of 3-dimensional dental models. Am J Orthod Dentofacial Orthop. 2020;157(3):4228. doi: 10.1016/j.ajodo.2019.10.012.

46. Morgan AJL, Hidalgo San Jose L, Jamieson WD, Wymant JM, Song B, Stephens P, et al. Simple and Versatile 3D Printed Microfluidics Using Fused Filament Fabrication. PLoS One. 2016;11(4):e0152023. doi: 10.1371/journal.pone.0152023.

47. Sommacal B, Savic M, Filippi A, Kühl S, Thieringer FM. Evaluation of Two 3D Printers for Guided Implant Surgery. Int J Oral Maxillofac Implants. 2018;33(4):743-6. doi: 10.11607/jomi.6074.

48. Muta S, Ikeda M, Nikaido T, Sayed M, Sadr A, Suzuki T, et al. Chairside fabrication of provisional crowns on FDM $3 \mathrm{D}$ printed PVA model. J Prosthodont Res. 2020;64(4):401-7. doi: 10.1016/j.jpor.2019.11.004.

49. Maschio F, Pandya M, Olszewski R. Experimental Validation of Plastic Mandible Models Produced by a "Low-Cost" 3-Dimensional Fused Deposition Modeling Printer. Med Sci Monit. 2016;22:943-57. doi: 10.12659/msm.895656.

50. Tao O, Kort-Mascort J, Lin Y, Pham HM, Charbonneau AM, ElKashty OA, et al. The Applications of 3D Printing for Craniofacial Tissue Engineering. Micromachines (Basel). 2019;10(7):48o. doi: 10.3390/mi10070480.

51. Miyanaji H, Zhang S, Lassell A, Zandinejad A, Yang L. Process Development of Porcelain Ceramic Material with Binder Jetting Process for Dental Applications. JOM. 2016;68(3):83141. doi: 10.1007/s11837-015-1771-3.

52. Tahayeri A, Morgan M, Fugolin AP, Bompolaki D, Athirasala A, Pfeifer CS, et al. 3D printed versus conventionally cured provisional crown and bridge dental materials. Dent Mater. 2018;34(2):192-200. doi: 10.1016/j.dental.2017.10.003.

53. Fina F, Goyanes A, Gaisford S, Basit AW. Selective laser sintering (SLS) 3D printing of medicines. Int $\mathrm{J}$ Pharm. 2017;529(1-2):285-93. doi: 10.1016/j.ijpharm.2017.06.082.

54. Mangano C, Mangano FG, Shibli JA, Roth LA, d'Addazio G, Piattelli A, et al. Immunohistochemical Evaluation of Peri-Implant Soft Tissues around Machined and Direct Metal Laser Sintered (DMLS) Healing Abutments in Humans. Int J Environ Res Public Health. 2018;15(8):1611. doi: 10.3390/ijerph15081611.

55. Msallem B, Sharma N, Cao S, Halbeisen FS, Zeilhofer HF, Thieringer FM. Evaluation of the Dimensional Accuracy of 3 D-Printed Anatomical Mandibular Models Using FFF,
SLA, SLS, MJ, and BJ Printing Technology. J Clin Med. 2020;9(3):817. doi: 10.3390/jcm9030817.

56. Barazanchi A, Li KC, Al-Amleh B, Lyons K, Waddell JN. Additive Technology: Update on Current Materials and Applications in Dentistry. J Prosthodont. 2017;26(2):156-63. doi: 10.1111/jopr.12510.

57. Tack P, Victor J, Gemmel P, Annemans L. 3D-printing techniques in a medical setting: a systematic literature review. Biomed Eng Online. 2016;15(1):115. doi: 10.1186/s12938-016-0236-4.

58. Kröger E, Dekiff M, Dirksen D. 3D printed simulation models based on real patient situations for hands-on practice. Eur $\mathrm{J}$ Dent Educ. 2017;21(4):e119-25. doi: 10.1111/eje.12229.

59. Wang C, Shi YF, Xie PJ, Wu JH. Accuracy of digital complete dentures: A systematic review of in vitro studies. J Prosthet Dent. 2020;125(2):249-56. doi: 10.1016/j.prosdent.2020.01.004. 6o. Adel-Khattab D, Giacomini F, Gildenhaar R, Berger G, Gomes C, Linow U, et al. Development of a synthetic tissue engineered three-dimensional printed bioceramic-based bone graft with homogenously distributed osteoblasts and mineralizing bone matrix in vitro. J Tissue Eng Regen Med. 2018;12(1):44-58. doi: 10.1002/term.2362.

61. Berger M, Probst F, Schwartz C, Cornelsen M, Seitz H, Ehrenfeld $\mathrm{M}$, et al. A concept for scaffold-based tissue engineering in alveolar cleft osteoplasty. J Craniomaxillofac Surg. 2015;43(6):830-6. doi: 10.1016/j.jcms.2015.04.023.

62. Wubneh A, Tsekoura EK, Ayranci C, Uludağ H. Current state of fabrication technologies and materials for bone tissue engineering. Acta Biomater. 2018;80:1-30. doi: 10.1016/j.actbio.2018.09.031.

63. Ma Y, Xie L, Yang B, Tian W. Three-dimensional printing biotechnology for the regeneration of the tooth and toothsupporting tissues. Biotechnol Bioeng. 2019;116(2):452-68. doi: 10.1002/bit.26882.

64. Salmi M, Ituarte IF, Chekurov S, Huotilainen E. Effect of build orientation in $3 \mathrm{D}$ printing production for material extrusion, material jetting, binder jetting, sheet object lamination, vat photopolymerisation, and powder bed fusion. Int $\mathrm{J}$ Collab Enterp. 2016;5(3-4):218. doi: 10.1504/IJCENT.2016.082334. 65. Thompson MK, Moroni G, Vaneker T, Fadel G, Campbell RI, Gibson I, et al. Design for Additive Manufacturing: Trends, opportunities, considerations, and constraints. CIRP Ann. 2016;65(2):737-6o. doi: 10.1016/j.cirp.2016.05.004.

66. Schönherr JA, Baumgartner S, Hartmann M, Stampfl J. Stereolithographic Additive Manufacturing of High Precision Glass Ceramic Parts. Materials (Basel). 2020;13(7):1492. doi: 10.3390/ma13071492. 